\title{
Introductory Biomedical Engineering Textbooks
}

\author{
Susan M. Blanchard, John D. Enderle \\ North Carolina State University/University of Connecticut
}

\section{Introduction}

Over the past fifty years, as the discipline of biomedical engineering has evolved, it has become clear that it is a diverse, seemingly all-encompassing field that includes such areas as biomechanics, biomaterials, bioinstrumentation, medical imaging, rehabilitation engineering, biomedical sensors, signal processing, biotechnology, and tissue engineering. Many of the textbooks that are currently available for introductory biomedical engineering courses are outdated, do not cover emerging topics such as tissue engineering, do not have example problems and exercises, require an in-depth knowledge of electrical engineering, are written at a level that is beyond the capabilities of most undergraduate students, or are written for the biomedical engineering technology student. ${ }^{1-6}$

\section{Discussion}

Nearly 20 experts have contributed to a new book, Introduction to Biomedical Engineering, that will be available late 1998. ${ }^{7}$ The text is written primarily for engineering students who have completed differential equations and basic courses in statics, dynamics, and linear circuits. Each chapter in the book begins with a short list of instructional objectives to help the students focus on the important topics that will be covered. The book contains numerous examples and exercises to help reinforce concepts and to develop problem solving skills. Within the text, MATLAB ${ }^{\circledR}$ (a matrix equation solver), SIMULINK ${ }^{\circledR}$ (an extension to MATLAB ${ }^{\circledR}$ for simulating dynamic systems) and LABView ${ }^{\circledR}$ (software interface for experiments) are used as computer tools to assist with problem solving.

Like its predecessors, this new biomedical engineering textbook cannot cover all of the possible topics that are considered to be within the domain of biomedical engineering, but it does cover those that are critical to the field and some of the emerging areas (Table 1). One of the goals of the book is to help students identify those areas of biomedical engineering that they want to learn more about through additional study in more advanced undergraduate and graduate courses.

\section{References}

1. J. D. Bronzino, Biomedical Engineering and Instrumentation - Basic Concepts and Applications. Boston: PWS Engineering, 1986.

2. J. J. Carr and J. M. Brown, Introduction to Biomedical Equipment Technology, $3^{\text {rd }}$ Ed. Upper Saddle River, NJ: Prentice Hall, 1998.

3. A. E. Profio, Biomedical Engineering. New York: John Wiley \& Sons, Inc., 1993.

4. J. G. Webster (Ed.), Medical Instrumentation: Application and Design, $3^{\text {rd }}$ Ed., New York: John Wiley \& Sons, 1989.

5. L. A. Geddes and L. E. Baker, Principles of Applied Biomedical Instrumentation, $3^{\text {rd }}$ Ed., New York: John Wiley \& Sons, Inc., 1989.

6. W. Welkowitz, S. Deutsch, and M. Akay, Biomedical Instruments: Theory and Design, $2^{\text {nd }}$ Ed., San Diego: Academic Press, 1992. 
7. J. D. Enderle, S. M. Blanchard, and J. D. Bronzino. Introduction to Biomedical Engineering. Academic Press. In Press.

Table 1: Chapters in Introduction to Biomedical Engineering

\begin{tabular}{|c|l|l|}
\hline Chapter & \multicolumn{1}{|c|}{ Title } & \multicolumn{1}{c|}{ Author(s) } \\
\hline 1 & Biomedical Engineering: A Historical Perspective & J. D. Bronzino \\
\hline 2 & Anatomy and Physiology & S. M. Blanchard \\
\hline 3 & Bioelectric Phenomena & J. D. Enderle \\
\hline 4 & Skeletal Muscle Mechanics & G. Yamaguchi and Jiping He \\
\hline 5 & Cardiovascular Mechanics & D. Schneck \\
\hline 6 & Compartmental Analysis & R. J. Fisher \\
\hline 7 & Physiological Modeling & J. D. Enderle \\
\hline 8 & Biomedical Sensors & Y. Mendelson \\
\hline 9 & Bioinstrumentation & S. M. Blanchard and H. Troy Nagle \\
\hline 10 & Biosignal Processing & $\begin{array}{l}\text { M. T. Young, C. L. Lucas, and } \\
\text { S. M. Blanchard }\end{array}$ \\
\hline 11 & & J. D. Enderle \\
\hline 12 & Lastem Identification and Optics & G. Coté, S. Rastegar, and LiHong Wang \\
\hline 13 & Radiation Imaging & J. D. Bronzino \\
\hline 14 & Ultrasound & K. K. Shung \\
\hline 15 & NMR-MRI & S. M. Wright \\
\hline 16 & Biomaterials & K. Merritt and S. Brown \\
\hline 17 & Tissue Engineering & B. Palsson \\
\hline 18 & Biotechnology & S. M. Blanchard and A.M. Stomp \\
\hline 19 & Assistive Technology and Rehabilitation Engineering & A. Y. J. Szeto \\
\hline 20 & Clinical Engineering and Electrical Safety & J. D. Bronzino \\
\hline 21 & Moral and Ethical Issues Associated with Medical & J. D. Bronzino \\
& Technology Innovation & \\
\hline
\end{tabular}

\section{SUSAN M. BLANCHARD}

Susan M. Blanchard graduated from Oberlin College with a B.A. degree in Biology in 1968 and from Duke University with the M.S. and Ph.D. degrees in Biomedical Engineering in 1980 and 1982, respectively. She worked for Rockwell International and the Departments of Surgery and Biomedical Engineering at Duke University before joining the Department of Biological and Agricultural Engineering at North Carolina State University in 1993 as an Associate Professor. She is a Senior Member of the Biomedical Engineering Society and the IEEE Engineering in Medicine and Biology Society (EMBS), a Fellow of the American Institute for Medical and Biological Engineering (AIMBE), and a member of ASEE. She was President of the IEEE EMBS in 1996. Her research interests are in cardiac electrophysiology and the electronic nose.

\section{JOHN D. ENDERLE}

John D. Enderle received the B.S., M.E., and Ph.D. degrees in Biomedical Bngineering, and M.E. degree in Electrical Engineering from Rensselaer Polytechnic Institute, Troy, New York, in 1975, 1977, 1980, and 1978, respectively. From 1981-1994, Enderle was a faculty member in the Department of Electrical Engineering. Dr. Enderle joined the National Science Foundation as Program Director for Biomedical Engineering \& Research Aiding Persons with Disabilities Program in 1994. In 1995, he joined the faculty of the University of Connecticut of the Electrical \& Systems Engineering Department. Dr. Enderle is a Fellow of the IEEE, Fellow of AIMBE, Fellow of the Rensselaer Alumni Association, and a member of the ASEE, Biomedical Engineering Society (Senior Member), Rocky Mountain Bioengineering Symposium and Sigma Xi, and President of the IEEE EMBS in 1997. His research interests include modeling physiological systems, system identification, signal processing, and control theory. 